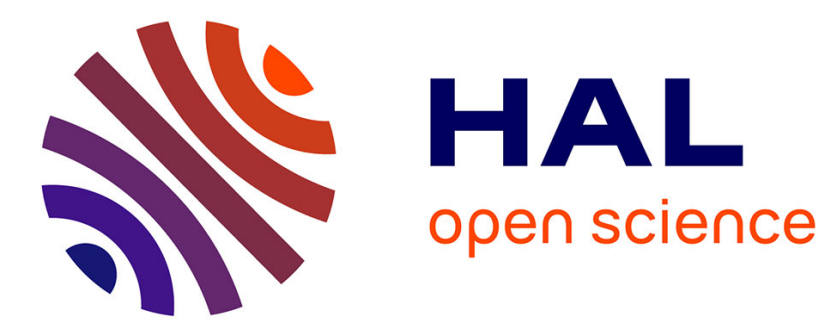

\title{
Metabolic response to an inflammatory challenge in pigs divergently selected for residual feed intake
}

\author{
Elodie Merlot, Hélène Gilbert, Nathalie Le Floc'H
}

\section{To cite this version:}

Elodie Merlot, Hélène Gilbert, Nathalie Le Floc'H. Metabolic response to an inflammatory challenge in pigs divergently selected for residual feed intake. Journal of Animal Science, 2016, 94 (2), pp.563-573. 10.2527/jas.2015-9445 . hal-02634451

\section{HAL Id: hal-02634451 \\ https://hal.inrae.fr/hal-02634451}

Submitted on 27 May 2020

HAL is a multi-disciplinary open access archive for the deposit and dissemination of scientific research documents, whether they are published or not. The documents may come from teaching and research institutions in France or abroad, or from public or private research centers.
L'archive ouverte pluridisciplinaire HAL, est destinée au dépôt et à la diffusion de documents scientifiques de niveau recherche, publiés ou non, émanant des établissements d'enseignement et de recherche français ou étrangers, des laboratoires publics ou privés. 


\title{
Metabolic response to an inflammatory challenge in pigs divergently selected for residual feed intake ${ }^{1}$
}

\author{
E. Merlot, $* \dagger^{2}$ H. Gilbert, $\$ \S$ and N. Le Floc' $h, * \dagger$ \\ *INRA, UMR1348 PEGASE, F-35590 Saint-Gilles, France; †Agrocampus Ouest, \\ UMR1348 PEGASE, F-35000 Rennes, France; \$INRA, UMR444 Laboratoire de Génétique Cellulaire, F-31326 \\ Castanet-Tolosan, France; §INRA, UMR1313 Génétique Animale et Biologie Intégrative, F-78352 Jouy-en-Josas, France
}

\begin{abstract}
Selection for residual feed intake (RFI), which is used to select animals for feed efficiency, also influences nutrient partitioning between growth and maintenance functions. This study was designed to investigate if selection for reduced RFI can alter the trade-off between growth and immunity and contributes to differences in metabolic responses to an inflammatory challenge. Piglets from 2 lines divergently selected on RFI (low: $\mathrm{RFI}^{-}, n=10$, and high: $\mathrm{RFI}^{+}, n=11$ ) were challenged at $55 \mathrm{~d}$ of age (on d 0) with complete Freund's adjuvant (CFA) to induce a noninfectious pneumonia. Plasma haptoglobin and nutrient concentrations (in fasted state and $2 \mathrm{~h}$ after feeding) were determined from $\mathrm{d}-1$ to $\mathrm{d} 7$, and tissue protein metabolism was determined on $\mathrm{d} 8$. Haptoglobin concentrations were greater from $\mathrm{d} 1$ to d 7 relative to $\mathrm{d}-1(P<0.01)$. Feed intake was less on $\mathrm{d} 1$ than on the other days $(P<0.001)$, as was total AA plasma concentrations at fasted state $(P<0.05)$. Fasted concentrations of His $(P=0.06)$ and Trp $(P=$ $0.05)$ tended to be less, those of Val were less $(P<$ $0.05)$, and fed concentrations of Lys were increased $(P<0.05)$ on $\mathrm{d} 7$ compared to $\mathrm{d}-1$. Uremia was less on $\mathrm{d} 7$ than on $\mathrm{d}-1$ at fasted state $(P<0.05)$,
\end{abstract}

whereas it did not vary at fed state $(P>0.1)$. Fasted glucose and insulin plasma concentrations were stable across days $(P>0.1)$. In the fed state and in only $\mathrm{RFI}^{+}$ pigs, glucose concentration was greater on $\mathrm{d} 1$ than on d 3, 5, and $7(P<0.05)$. Total AA, Gln, Ile, Leu, Pro $(P<0.05)$, and hydroxyproline $(P=0.07)$ were less in $\mathrm{RFI}^{-}$than $\mathrm{RFI}^{+}$pigs at fed state, whereas Ala and Gly were less in $\mathrm{RFI}^{-}$pigs at fasted and fed states $(P<0.05)$. Citrulline $(P<0.05)$ and Met $(P<0.01)$ concentrations were greater in $\mathrm{RFI}^{-}$than $\mathrm{RFI}^{+}$pigs in the fasted state, whereas Asp was greater in $\mathrm{RFI}^{-}$ pigs in both fasted and fed states $(P<0.05)$. On $\mathrm{d} 8$, liver and LM protein synthesis tended to be lower $(P=$ 0.07 and 0.09 , respectively) and liver calpain activity was greater $(P=0.07)$ in $\mathrm{RFI}^{-}$than $\mathrm{RFI}^{+}$pigs. Liver and LM proteasome did not differ between lines $(P>$ $0.1)$. The metabolic differences between lines were not associated with differences in feed intake, ADG between $\mathrm{d}-1$ and $\mathrm{d} 8$, and haptoglobin concentration $(P>0.1)$. Thus, it seems that that, using different metabolic strategies, both lines coped similarly with the CFA challenge. Contrary to our hypothesis, this experiment showed, in young pigs, no advantage of $\mathrm{RFI}^{+}$ animals in response to an inflammatory challenge.

Key words: amino acids, glucose, inflammation, pig, protein turnover, residual feed intake

\section{INTRODUCTION}

\footnotetext{
${ }^{1}$ We acknowledge the students and staff from INRA PEGASE and GenESI units (Yvon Billon, Philippe Ganier, Régis Janvier, Francis Le Gouevec, Nadine Mézière, Jean-Noël Thibault, and Marie Rekiba) for their technical help. This work was funded by the INRA PHASE division, the INRA GA division, and a grant from the French National Research Agency (ANR-08-GENM038 PIG_FEED Project).

${ }^{2}$ Corresponding author: elodie.merlot@rennes.inra.fr

Received June 22, 2015.

Accepted November 25, 2015.
}

Residual feed intake (RFI) is a criterion used to select pigs for feed efficiency (Gilbert et al., 2007). Briefly, for a similar production level, a high-RFI animal eats more than predicted by its BW gain and body composition and thus uses nutrients less efficiently than a low-RFI animal. Compared with high-RFI pigs, low-RFI pigs have reduced heat production due to reduced daily feed intake (Young et al., 2011), physical 
activity (Meunier-Salaun et al., 2014), and basal metabolic rate (Barea et al., 2010), indicating that selection for RFI influences the nutrient partitioning between production and maintenance functions. Although required for economic reasons, there are concerns that this altered trade-off could increase susceptibility to stressors and diseases because of an inadequate reallocation of nutrients to nonproductive functions when needed.

In particular, immune activation imposes decreased resource acquisition due to sickness-induced anorexia (Pastorelli et al., 2012) and additional nutritional requirements to cover a greater protein synthesis in immune and hepatic compartments (Iseri and Klasing, 2013, in chickens) and energy expenditure for the fever and oxidative responses (Benhariz et al., 1997, in children). Whether highly efficient pigs display an impaired immunity and resistance to diseases has not been clearly established until now (Clapperton et al., 2005; Doeschl-Wilson et al., 2009; Dunkelberger et al., 2015).

This study was designed to investigate if energy and protein metabolism would be more affected by inflammation in low-RFI pigs than in high-RFI pigs. Piglets obtained from lines divergently selected for RFI were challenged with complete Freund's adjuvant (CFA), known to induce a noninfectious lung inflammation and substantial changes in AA metabolism (Melchior et al., 2004). To assess the metabolic response to inflammation, plasma nutrient concentrations were measured during the 7 following days, and tissue protein metabolism was measured on the eighth day.

\section{MATERIALS AND METHODS}

The care and use of animals were performed in accordance with the guidelines of the French Ministry of Agriculture and Fisheries for animal research. The scientific and technical staffs obtained an agreement from the French veterinary services to conduct animal research. The protocol was approved by the local ethical committee (CREEA Bretagne, nº-2009-NLF-02).

\section{Animal and Experimental Design}

Purebred French Large White female pigs were produced in the course of a divergent selection experiment on RFI in the INRA experimental facilities (GenESI, Le Magneraud and Rouillé, France). The selection program, started at INRA in 2000, was previously described (Gilbert et al., 2007; Le Naou et al., 2012). Briefly, daily feed intake (DFI) and ADG from 35 to $95 \mathrm{~kg}$ were recorded for male candidates for selection together with back fat thickness at $95 \mathrm{~kg}$ (UBT). An RFI selection index was computed as a linear combination of those traits to account for nutritional growth requirement as follows:

$$
\mathrm{RFI}=\mathrm{DFI}-(1.24 \times \mathrm{ADG})-(31.9 \times \mathrm{UBT}),
$$

in which RFI, DFI, and ADG are measured in grams per day and UBT is measured in millimeters. In the present study, pigs from the seventh and eighth generations (G7 and G8) were considered. Sibs bred in the selection farm showed significant line differences for DFI (the contrasts between estimated breeding values in the low RFI $\left[\mathbf{R F I}^{-}\right]$and high RFI $\left[\mathbf{R F I}^{+}\right]$pigs were -242 and $-266 \mathrm{~g} / \mathrm{d}$ in $\mathrm{G} 7$ and G8, respectively), feed conversion ratio ( -0.28 and -0.31 in $\mathrm{G} 7$ and $\mathrm{G} 8$, respectively), and RFI ( -141 and $-153 \mathrm{~g} / \mathrm{d}$ in $\mathrm{G} 7$ and G8, respectively, i.e., -3.28 and -3.56 genetic standard deviations of the trait). Additionally, significant line differences were found for lean meat content of the carcass $(+2.9$ and $+3.1 \%$ in G7 and G8, respectively).

The trial was performed in 2 successive replicates 3 mo apart using a total of 21 pigs. At weaning ( $28 \mathrm{~d}$ of age), female piglets from the high-RFI ( $n=6$ and 5 in replicates 1 and 2, respectively) and low-RFI ( $n=5$ per replicate) lines were transferred from the selection herd to the experimental facilities of INRA PEGASE (Saint-Gilles, France). They were kept in individual cages $(1.2 \times 0.7 \mathrm{~m}$ stainless-steel cages, providing visual contact with each other) in a room maintained at $26^{\circ} \mathrm{C}$. Piglets from the $\mathrm{RFI}^{-}$(more efficient line) and $\mathrm{RFI}^{+}$(less efficient line) groups were chosen so that several litters per line were represented ( $7 \mathrm{RFI}^{-}$and $8 \mathrm{RFI}^{+}$sows) and their BW (8.7 \pm 0.9 and $9.0 \pm 1.1 \mathrm{~kg}$, respectively, and statistically not different) was representative of the average weaning BW in their contemporary group.

Two weeks after weaning (10 kg BW), pigs were fasted overnight, and a jugular catheter was inserted under general anesthesia, using a premedication with 15 $\mathrm{mg} / \mathrm{kg}$ of ketamine injected intramuscularly (Imalgène 1000, Merial, Lyon, France), followed by inhalation of sevofluorane (Sevoflurane, Baxter, Maurepas, France) using a facemask. After surgery, antibiotics $(0.5 \mathrm{mg} / \mathrm{mL}$ ampicillin; Coophavet, Ancenis, France) were administrated intramuscularly. The catheters were flushed daily with $10 \mathrm{~mL}$ of sterile saline solution containing $2.5 \mathrm{~mL}$ of heparin $(5,000 \mathrm{U} / \mathrm{mL})$. Twelve days after (at $55 \pm 2 \mathrm{~d}$ of age and $14.90 \pm 0.02 \mathrm{~kg} \mathrm{BW}$ ), pigs were fasted overnight, and a lung inflammation was induced according to the procedure described by Le Floc'h et al. (2008) modified as follows. An emulsion composed of $3 \mathrm{~mL}$ of CFA and $7 \mathrm{~mL}$ of saline was intravenously injected between 0800 and $0900 \mathrm{~h}$ on 2 consecutive days (approximately $2 / 3$ on the first day [d 0] and $1 / 3$ on the second day [d 1]) to avoid mortality. As described by Edwards and Slauson (1983), CFA injection in the jugular vein induced interstitial pneumonia. The experimental period started the day before the injection of CFA $(d-1)$ and ended on $d 8$. 
Pigs were fed a standard starter diet for the first $10 \mathrm{~d}$ after weaning and then a weaner diet until the end of the trial (Table 1). During the experimental period, pigs had free access to water. They were fed twice a day (at 0900 and $1500 \mathrm{~h}$ ), except on d 0, when they were fed only at $1500 \mathrm{~h}$, and individual feed consumption was recorded daily. The feed was removed from the trough at $1700 \mathrm{~h}$ the day before each blood sampling to ensure that blood was sampled after an overnight fasting. Rectal temperature was recorded with digital electronic thermometers (Vetarvor, Ingwiller, France) at 0900 and $1600 \mathrm{~h}$ from $\mathrm{d}-1$ to $\mathrm{d} 3$. Pigs were weighed weekly.

\section{Blood and Tissue Sampling}

Blood $(5 \mathrm{~mL})$ was collected before $(0730 \mathrm{~h})$ and 2 $\mathrm{h}$ after the morning meal on the day before $(\mathrm{d}-1)$ and $1,3,5$, and $7 \mathrm{~d}$ after the challenge ( 1 to 7 ). Blood was collected into heparin (100 units per tube, SanofiAventis, France) and dry tubes; plasma and sera were centrifuged $\left(4^{\circ} \mathrm{C}, 2,500 \times \mathrm{g}, 15 \mathrm{~min}\right)$, aliquoted, and kept at $-20^{\circ} \mathrm{C}$ until analysis.

All pigs were killed $8 \mathrm{~d}$ after the challenge. Before slaughter and $2 \mathrm{~h}$ after the morning meal, each pig was injected with a flooding dose of valine $\left(20 \%{ }^{15} \mathrm{~N}\right.$ valine and $80 \%$ of unlabeled valine) to measure tissue protein synthesis rate (Jamin et al., 2012). Blood (2 mL) was collected in heparinized ice-cooled tubes just before and 7 and 14 min after the injection. Blood was centrifuged $\left(4^{\circ} \mathrm{C}, 2,500 \mathrm{x} \mathrm{g}, 15 \mathrm{~min}\right)$, and plasma was stored at $-20^{\circ} \mathrm{C}$ until analysis. Fifteen minutes after the valine injection, piglets were euthanized with a lethal dose of T61 injected intravenously (Intervet, Beaucouzé, France) and exsanguinated. Lungs were inspected to observe their general aspects, texture, and lesions. Samples of liver and LM were immediately collected, frozen in liquid nitrogen, and stored at $-80^{\circ} \mathrm{C}$.

\section{Plasma Haptoglobin and Nutrients}

Plasma haptoglobin was determined in samples collected at fasted state by a colorimetric assay (phase haptoglobin assay T801, Tridelta Development Ltd., Maynooth, Ireland). Plasma glucose, urea, insulin, and AA concentrations were determined on blood samples collected every $2 \mathrm{~d}$, before and $2 \mathrm{~h}$ after the morning meal. Plasma glucose and urea were determined in duplicate using commercial kits (Biomerieux, Craponne, France) and a Konelab 20i device (Thermo Fisher Scientific, Courtaboeuf, France). Plasma concentrations of insulin were measured using a RIA kit (INSULIN-CT, CisBio Bioassays, Codolet, France). The intra-assay $\mathrm{CV}$ were below $5 \%$.
Table 1. Ingredients and chemical composition of diets (as-fed basis)

\begin{tabular}{lcc}
\hline \hline Item & Starter & Weaner \\
\hline Ingredient, \% & - & 23.2 \\
Wheat & - & 25.0 \\
Corn & 45.7 & 22.6 \\
Barley & 20.0 & - \\
Dried whey & 17.5 & 24.3 \\
Soybean meal & 8.0 & - \\
Lactose & 2.3 & 0.45 \\
Vegetable (corn) oil & 1.5 & 0.97 \\
Calcium carbonate & 0.68 & - \\
Monocalcium phosphate & - & 1.1 \\
Dicalcium phosphate & - & 0.40 \\
Sodium chloride & 0.50 & 0.50 \\
Vitamin-mineral premix ${ }^{1}$ & 0.38 & 0.7 \\
L-Lysine HCL & 0.23 & 0.18 \\
DL-Methionine & 0.15 & 0.15 \\
L-Threonine & 0.35 & 0.35 \\
L-Tryptophan & 0.24 & 0.01 \\
3-Phytase & & \\
Chemical composition & 19.0 & 18.6 \\
CP, \% & 1.25 & 9.4 \\
Digestible lysine, \% & 10.6 & \\
NE, kJ/g & & \\
\hline & &
\end{tabular}

${ }^{1}$ Premix provided the following amount of vitamins and minerals per kilogram of diets (as-fed basis): the starter diet = vitamin A, 15,000 IU; vitamin D3, 3000 IU; vitamin E, 40 IU; iron sulfate, $104 \mathrm{mg}$; copper sulfate, 20 $\mathrm{mg}$; zinc oxide, $99 \mathrm{mg}$; manganese oxide, $40 \mathrm{mg}$; carbonate cobalt, $2 \mathrm{mg}$; sodium selenium, $0.3 \mathrm{mg}$; and calcium iodate, $1 \mathrm{mg}$; the weaner diet = vitamin A, 10,000 IU; vitamin $\mathrm{D}_{3}, 2,000 \mathrm{IU}$; vitamin E, $20 \mathrm{mg}$; iron sulfate, $104 \mathrm{mg}$; copper sulfate, $20 \mathrm{mg}$; zinc oxide, $99 \mathrm{mg}$; manganese oxide, $40 \mathrm{mg}$; carbonate cobalt, $1 \mathrm{mg}$; Se as sodium selenium, $0.3 \mathrm{mg}$; and calcium iodate, $0.6 \mathrm{mg}$.

${ }^{2}$ Myo-inositol-hexakisphosphate-phosphohydrolase3.1.3.8, Natuphos (BASF, Limburgerhof, Germany).

PlasmaAA concentrations were determined using an ultra HPLC system (Waters Acquity Ultra Performance LC system, Waters, Guyancourt, France) coupled to an Acquity tunable UV detector and a mass detector (SQD detector) to identify the few coeluting chromatographic peaks. The column was a MassTrak AAA column $(2.1 \times$ $150 \mathrm{~mm}$ ). Amino acid derivatization was performed using an AccQ· Tag Ultra derivatization (MassTrak AAA Waters, Milford, MA). The Empower 2chromatography software (Waters corporation, Milford, MA, USA) was used for instrument control and data acquisition.

\section{Tissue Protein Metabolism}

Activities of the proteasome, the key enzyme of the ubiquitin-dependent proteolysis, and of calpains ( $\mu$-calpain and $\mathrm{m}$-calpain) involved in $\mathrm{Ca}^{2+}$-dependent proteolysis were assayed in the LM and the liver as described by Le Naou et al. (2012).

Tissue protein synthesis rate was determined in liver and LM. Plasma free valine enrichment $\left(\mathbf{S}_{\mathbf{A}}\right)$ was 
determined by gas chromatography coupled with a mass spectrometer (Agilent Technology, Santa Clara, CA) after derivatization with $N$-tert-butyldimethylsilyl $\mathrm{N}$-methyl-trifluoroacetamide. Protein-bound valine enrichment $\left(\mathbf{S}_{\mathbf{B}}\right)$ was measured by gas chromatography coupled to an isotopic ratio mass spectrometer (Isochrom, Fisons Instruments, Manchester, UK) after derivatization with ethyl chloroformate. The fractional protein synthesis rate $(\mathbf{K S}, \% / \mathrm{d})$, corresponding to the percentage of proteins newly synthesized per day, was calculated as follows: $\mathrm{KS}=\left(\mathrm{S}_{\mathrm{B}} \times 100\right) /\left(\mathrm{S}_{\mathrm{A}} \times \mathrm{t}\right)$, where $\mathrm{S}_{\mathrm{B}}$ represents plasma enrichment, $\mathrm{S}_{\mathrm{A}}$ is the tissue protein enrichment, and $\mathbf{t}$ is the time elapsed between the injection of valine and animal bleeding.

\section{Statistical Analysis}

The experimental unit was the piglet. Growth performance and tissue metabolic activities were analyzed by ANOVA using the MIXED procedure of SAS (SAS Inst. Inc., Cary, $\mathrm{NC})$, with line $\left(\mathrm{RFI}^{+}\right.$or $\left.\mathrm{RFI}^{-}\right)$and replicate (first or second replicate) as fixed effects. Plasma metabolite concentrations, BW, and feed intake were analyzed as time-repeated measures with the MIXED procedure (SAS) using the effects of day $(\mathrm{d}-1,1,3$, 5 , and 7), replicate, and line as main effects, as well as the corresponding interactions. The adequate covariance structure was selected as that minimizing Akaike's information criterion and Schwarz's Bayesian criterion for each model. Fasted and fed plasma nutrient concentrations were analyzed separately. When line, day, or interaction effects were significant $(P<0.05)$, differences between $\mathrm{RFI}^{+}$and RFI - or between days were tested by a Bonferroni test and considered as significant for $P<0.05$. However, values with $0.1<P<0.05$ were considered as trends and are discussed.

\section{RESULTS}

\section{Feed Intake and Growth Performance}

Feed consumption was influenced by the day effect $(P<0.001)$. It was lower on $\mathrm{d} 0$ relative to all other days $(P<0.001)$ and greater on $\mathrm{d} 7$ than on $\mathrm{d}-1,1,2$, and $4(P<0.01$; Fig. 1A). Both lines of pigs had similar $\mathrm{BW}$ on $\mathrm{d}-1(15.0 \pm 0.2$ vs. $14.8 \pm$ $0.02 \mathrm{~kg})$, ADFI (697 and $\pm 25 \mathrm{~g} / \mathrm{d}$ for $\mathrm{RFI}^{-}$pigs and $665 \pm 24 \mathrm{~g} / \mathrm{d}$ for $\mathrm{RFI}^{+}$pigs $), \mathrm{ADG}(455 \pm 34 \mathrm{~g} / \mathrm{d}$ for $\mathrm{RFI}-$ pigs and $470 \pm 33 \mathrm{~g} / \mathrm{d}$ for $\mathrm{RFI}^{+}$pigs), and feed consumption from $\mathrm{d}-1$ to $\mathrm{d} 8(P>0.1)$. There was no line $\times$ day interaction for those variables $(P>0.1)$. At slaughter, the relative weights of liver $(30 \pm 2 \mathrm{~g} / \mathrm{kg}$ $\mathrm{BW})$ and lung $(17 \pm 3 \mathrm{~g} / \mathrm{kg} \mathrm{BW})$ did not differ between the 2 lines $(P>0.1)$.
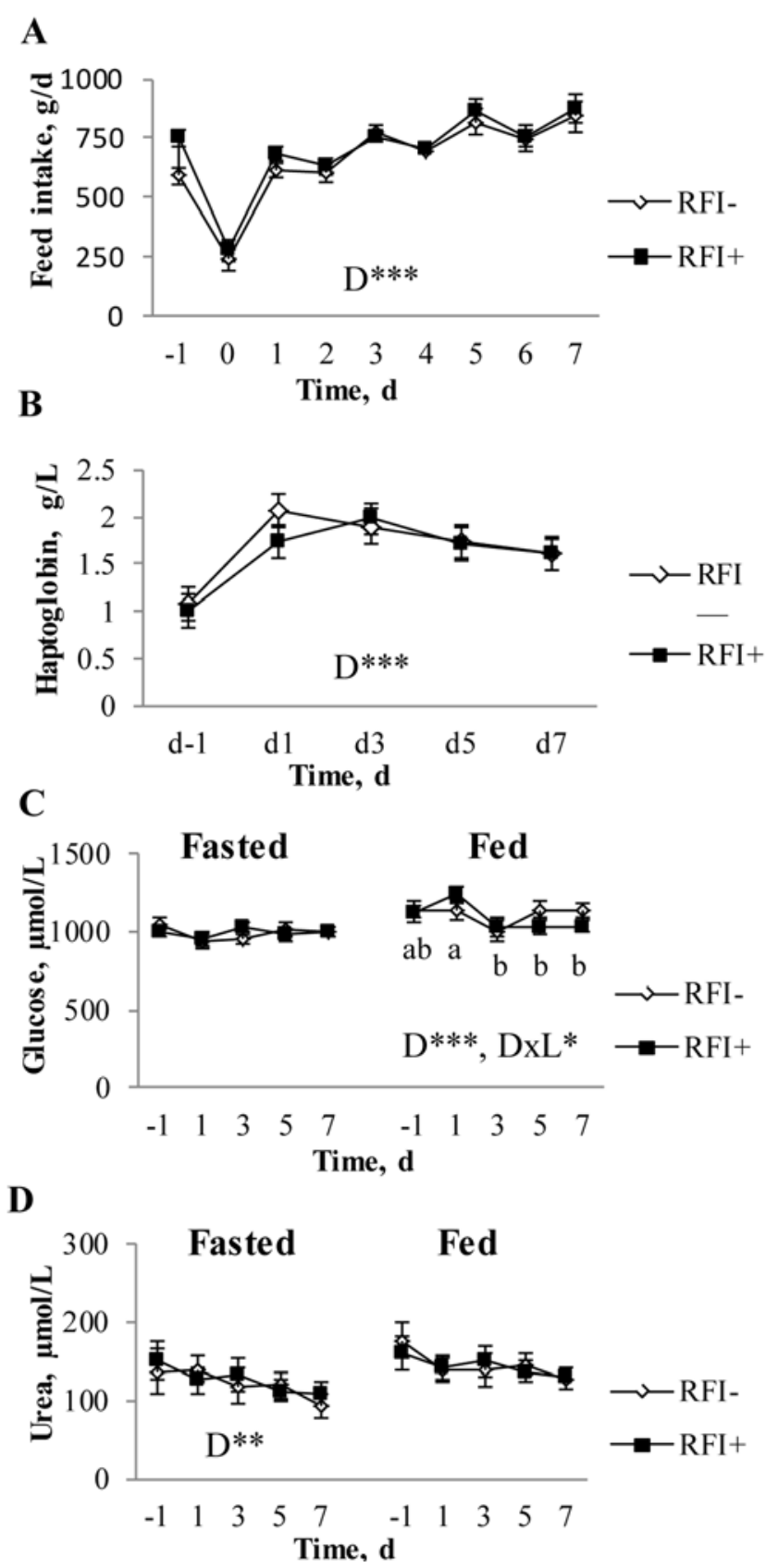

Figure 1. (A) Feed intake, (B) haptoglobin concentration, and (C) glucose and (D) urea concentrations in fasted and fed states in piglets divergently selected on low or high residual feed intake $\left(\mathrm{RFI}^{-}\right.$and $\left.\mathrm{RFI}^{+}\right)$and treated with complete Freund's adjuvant on $\mathrm{d} 0$. The presented data are least squares means \pm SE. The day $(\mathrm{D})$, line $(\mathrm{L})$, and their interaction $(\mathrm{D} \times \mathrm{L})$ effects are indicated on the charts when significant $(* P<0.05 ; * * P<0.01 ; * * * P<0.01)$. For glucose, means of $\mathrm{RFI}^{+}$pigs without a common superscript differ $(P<0.05)$.

\section{Indicators of Inflammation}

Immediately after the first administration of CFA, all pigs became lethargic and exhibited an increased respiration rate as previously described (Melchior et al., 2004, 2005; Le Floc'h et al., 2008). Pigs developed a febrile response $\left(40.7^{\circ} \mathrm{C}\right.$ and $40.1^{\circ} \mathrm{C} \pm 0.1^{\circ} \mathrm{C}$ at $1600 \mathrm{~h}$ on $\mathrm{d} 0$ and 1 , respectively, vs. $39.5^{\circ} \mathrm{C} \pm 0.1^{\circ} \mathrm{C}$ on $\mathrm{d}-1 ; P<0.01)$. After $2 \mathrm{~d}$, the clinical signs and rectal temperature decreased $\left(39.4^{\circ} \mathrm{C}\right.$ and $39.5^{\circ} \mathrm{C} \pm$ 
Table 2. Plasma concentrations $(\mathrm{nmol} / \mathrm{mL})$ of AA that were transiently decreased following treatment with complete Freund adjuvant, measured in low and high residual feed intake pigs ( $\mathrm{RFI}^{-}$and $\mathrm{RFI}^{+}$lines)

\begin{tabular}{|c|c|c|c|c|c|c|c|}
\hline \multirow[b]{2}{*}{ Item } & \multirow[b]{2}{*}{$\begin{array}{c}\text { Nutritional } \\
\text { status }\end{array}$} & \multirow[b]{2}{*}{$\mathrm{RFI}^{-1}$} & \multirow[b]{2}{*}{$\mathrm{RFI}^{+1}$} & \multirow[b]{2}{*}{ SEM } & \multicolumn{3}{|c|}{$P$-value } \\
\hline & & & & & Line & Day $^{2}$ & $\begin{array}{c}\text { Line } x \\
\text { day }\end{array}$ \\
\hline \multirow[t]{2}{*}{ Total AA } & Fasted & 4,225 & 4,346 & 110 & 0.45 & $<0.0001$ & 0.48 \\
\hline & Fed & 5,600 & 6,339 & 219 & 0.03 & $<0.001$ & 0.28 \\
\hline \multirow[t]{2}{*}{ Ala } & Fasted & 534 & 593 & 19 & 0.03 & $<0.0001$ & 0.72 \\
\hline & Fed & 712 & 818 & 36 & 0.05 & 0.0002 & 0.35 \\
\hline \multirow[t]{2}{*}{ Asn } & Fasted & 77 & 68 & 4 & 0.15 & 0.015 & 0.84 \\
\hline & Fed & 139 & 154 & 9 & 0.25 & 0.01 & 0.19 \\
\hline \multirow[t]{2}{*}{ Asp } & Fasted & 20 & 16 & 1 & 0.0004 & $<0.0001$ & 0.34 \\
\hline & Fed & 26 & 22 & 1 & 0.02 & $<0.0001$ & 0.92 \\
\hline \multirow[t]{2}{*}{ Gln } & Fasted & 641 & 644 & 23 & 0.92 & $<0.0001$ & 0.47 \\
\hline & Fed & 726 & 792 & 20 & 0.03 & $<0.0001$ & 0.68 \\
\hline \multirow[t]{2}{*}{ Glu } & Fasted & 250 & 194 & 15 & 0.01 & $<0.001$ & 0.25 \\
\hline & Fed & 303 & 256 & 18 & 0.08 & $<0.001$ & 0.45 \\
\hline \multirow[t]{2}{*}{ Gly } & Fasted & 962 & 1143 & 46 & 0.01 & $<0.0001$ & 0.34 \\
\hline & Fed & 925 & 1111 & 57 & 0.03 & 0.0007 & 0.29 \\
\hline \multirow[t]{2}{*}{ Hypro } & Fasted & 102 & 106 & 5 & 0.55 & 0.25 & 0.77 \\
\hline & Fed & 97 & 112 & 5 & 0.07 & 0.004 & 0.78 \\
\hline \multirow[t]{2}{*}{ Ile } & Fasted & 132 & 133 & 4 & 0.87 & 0.0001 & 0.68 \\
\hline & Fed & 172 & 197 & 6 & 0.005 & 0.0009 & 0.03 \\
\hline \multirow[t]{2}{*}{ Leu } & Fasted & 147 & 141 & 5 & 0.44 & 0.0002 & 0.70 \\
\hline & Fed & 198 & 223 & 8 & 0.03 & 0.0007 & 0.04 \\
\hline \multirow[t]{2}{*}{ Pro } & Fasted & 245 & 254 & 8 & 0.45 & $<0.0001$ & 0.60 \\
\hline & Fed & 217 & 255 & 17 & 0.02 & $<0.0001$ & 0.31 \\
\hline \multirow[t]{2}{*}{ Ser } & Fasted & 175 & 193 & 11 & 0.26 & 0.03 & 0.21 \\
\hline & Fed & 217 & 255 & 16 & 0.11 & 0.09 & 0.46 \\
\hline
\end{tabular}

${ }^{1}$ Least squares means calculated from the concentrations $(\mathrm{nmol} / \mathrm{mL}$ ) measured every second day from $\mathrm{d}-1$ to $\mathrm{d} 7$ after 1 night fasting (fasted state) and $2 \mathrm{~h}$ after the daily meal (fed state).

${ }^{2}$ For the listed AA, the temporal patterns showed decreased concentrations on $\mathrm{d} 1$ in both fasted and fed states, with significantly reduced concentrations on $\mathrm{d} 1$ than on $\mathrm{d}-1,5$, or 7 , except for Asn, hydroxyproline (Hypro), and Ser. Serine and Hypro concentrations were decreased on d 1 in only fasted and fed states, respectively. Asparagine differences between days were not significant, although visually the temporal pattern was close to those of the other AA in this table.

$0.1^{\circ} \mathrm{C}$ on $\mathrm{d} 2$ and 3 at $1600 \mathrm{~h}$, respectively), and piglets seemed to recover.

Plasma haptoglobin concentration was greater from $\mathrm{d} 1$ to $\mathrm{d} 7$ than on $\mathrm{d}-1(P<0.01$; Fig. 1B), and the 2 lines did not differ $(P>0.1)$. At slaughter, on d 8, lungs of piglets presented clear signs of inflammation characterized by the presence of small inflammatory foci in the parenchyma, as already reported (Melchior et al., 2004).

\section{Plasma Glucose, Insulin, and Urea}

Plasma variables were measured every $2 \mathrm{~d}$ from $\mathrm{d}$ -1 to $\mathrm{d} 7$. There was no effect of day $(P>0.1)$ on concentrations of glucose measured in fasted conditions and $2 \mathrm{~h}$ after feeding (Fig. 1C), insulin (21 \pm 9 and $57 \pm$
$30 \mu \mathrm{IU} / \mathrm{mL}$ before and $2 \mathrm{~h}$ after feeding, respectively), and glucose:insulin ratio $(52 \pm 15$ and $25 \pm 16 \mu \mathrm{mol} /$ $\mathrm{mIU}$ before and $2 \mathrm{~h}$ after feeding, respectively). Plasma uremia was influenced by day in fasted state $(P<0.05)$, with lower concentrations on $\mathrm{d} 7$ than on $\mathrm{d} 1(P<0.05)$, whereas it did not vary in the fed state (Fig. 1D).

The 2 lines did not differ for fasted glucose, fasted and postprandial insulin, and urea concentrations $(P>$ $0.1)$. There was a day $\times$ line interaction for postprandial glucose concentration $(P<0.05)$, which did not differ across days in $\mathrm{RFI}^{-}$pigs but was greater on $\mathrm{d} 1$ than on $\mathrm{d} 3,5$, and 7 in $\mathrm{RFI}^{+}$pigs $(P<0.05)$.

\section{Plasma AA Concentrations}

Total AA concentration was lower on $\mathrm{d} 1$ relative to the other days in the fasted state $(P<0.05)$ and to $\mathrm{d}$ 3 and 7 in the fed state $(P<0.05$; Table 2$)$. Among individual AA, concentrations of Ala, Asp, Gln, Glu, Gly, and Leu displayed a pattern comparable to total AA. The examples of Gln, Gly, and Asp are provided in Fig. $2 \mathrm{~A}$ to $2 \mathrm{C}$. The temporal patterns for Asn, Ile, hydroxyproline (Hypro), Pro, and Ser were also quite similar to those for total AA. For Asn, the concentration measured on $\mathrm{d} 1$ was lower than that on $\mathrm{d} 5$ in the fasted state $(P$ $<0.05)$. For Ile and Pro, d 1 concentrations were lower than those on $\mathrm{d} 3$ and 5 in the fasted state $(P<0.01)$ and $\mathrm{d} 3$ and 7 in the fed state (Ile: $P=0.07$ and $P<0.01$, respectively; Pro: $P<0.01)$. Hydroxyproline concentration was stable across days in the fasted state $(P>0.1)$ but lower on $\mathrm{d} 1$ than on $\mathrm{d} 3$ and 7 in the fed state $(P<$ $0.05)$. Serine concentrations were lower on $d 1$ than on d 5 in the fasted state $(P<0.5)$ but stable across days in the fed state $(P>0.1)$. On d 7, Ala $(P<0.01)$ and Glu $(P<0.01)$ concentrations in the fed state were greater than on $\mathrm{d}-1(P<0.05)$, whereas for other AA in Table 2 , concentrations in fed and fasted states were comparable to the $\mathrm{d}-1$ prechallenge concentrations $(P>0.1)$.

Some AA concentrations varied differently from total AA across days (Table 3). For His, Trp, and Val, the day effect was significant (Val, $P<0.01$; Fig. 2D) or tended to be significant (His and $\operatorname{Trp}, P<0.1$; Table 3 ) in the fasted state but not in the fed state $(P>0.1)$. Overall, the concentrations decreased across days and were lower on $\mathrm{d} 7$ than on $\mathrm{d}-1(P<0.05$ for Trp and Val, $P=0.06$ for His). In contrast, in the fed state, Lys concentrations were greater on $\mathrm{d} 7$ than on $\mathrm{d}-1(P<0.05$; Fig. $2 \mathrm{E})$, and Thr tended to be influenced by the day effect in the same direction $(P=0.06)$, whereas their fasted state concentrations did not vary across days $(P>0.1)$.

Plasma total AA concentrations did not differ between $\mathrm{RFI}^{-}$and $\mathrm{RFI}^{+}$in the fasted state $(P>0.1)$, whereas they were lower in $\mathrm{RFI}^{-}$pigs than in $\mathrm{RFI}^{+}$ pigs in the fed state regardless of the day $(P<0.05$; 

A
Fasted
Fed
D
Fasted
Fed
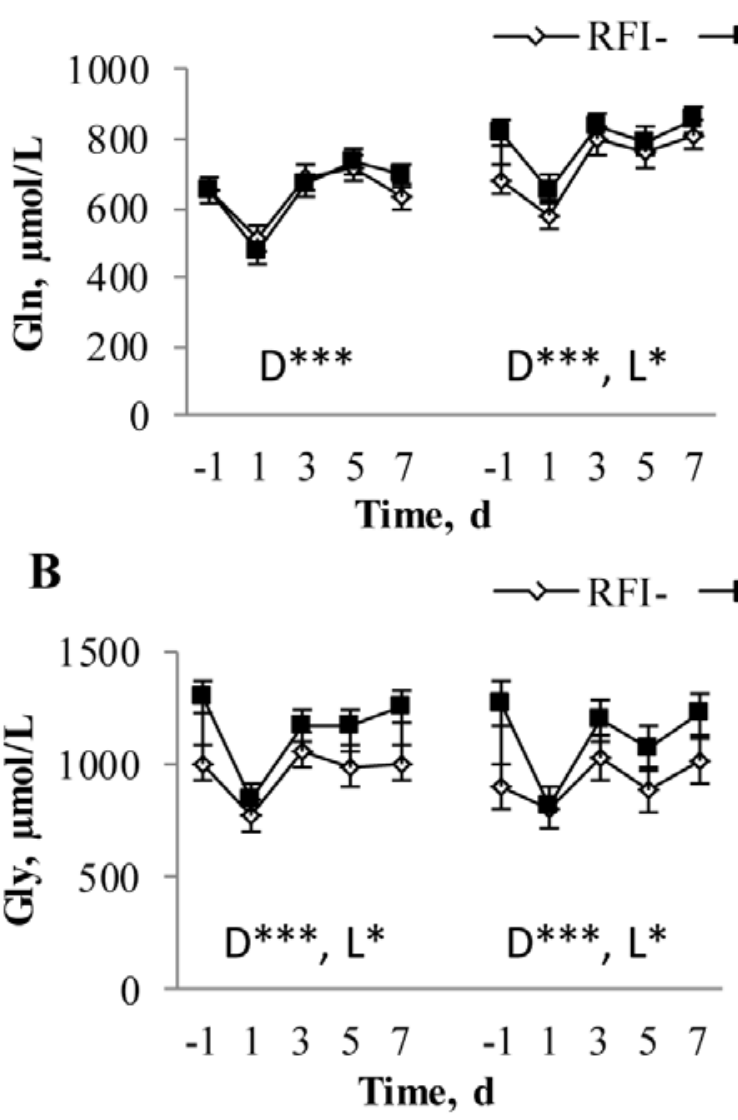

C

Time, d
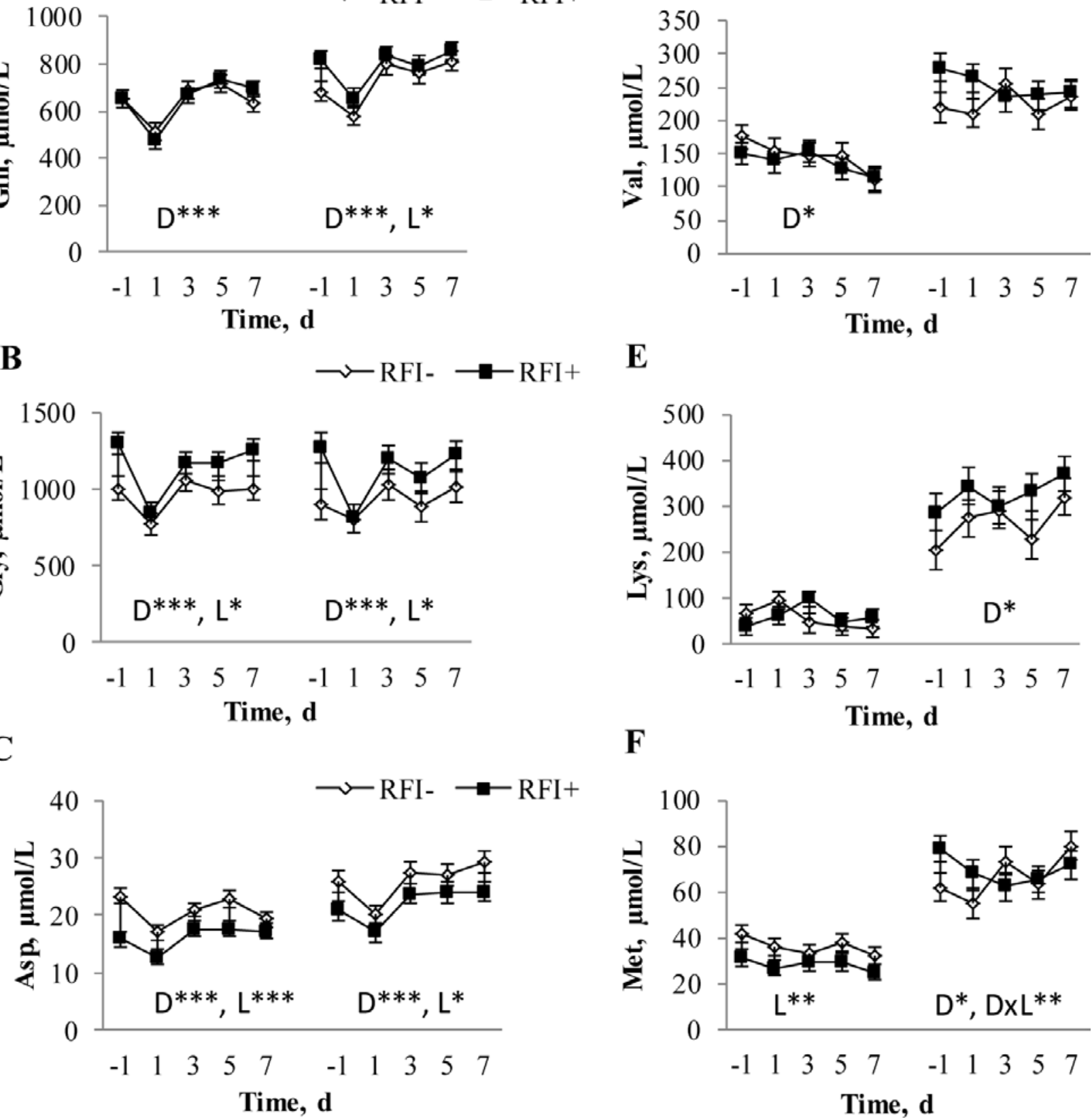

E

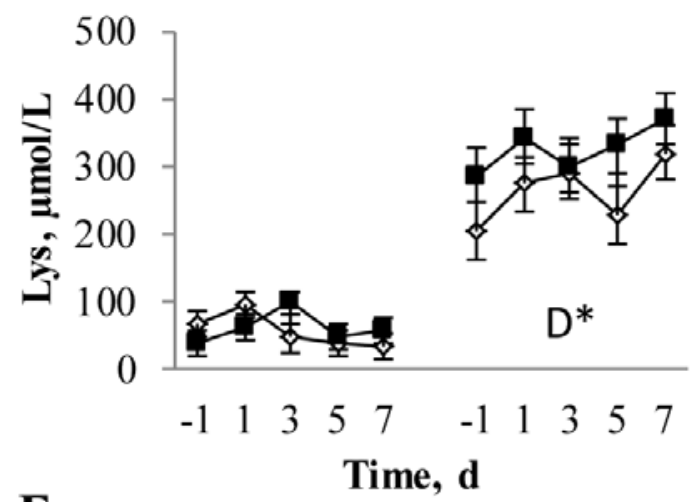

F

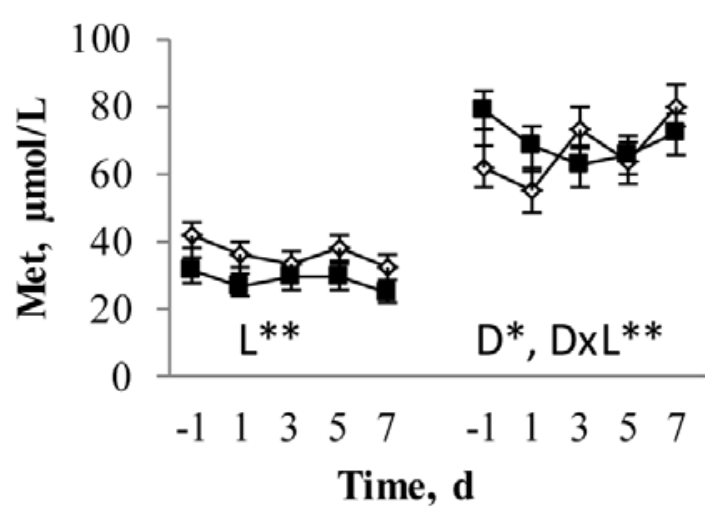

Figure 2. Plasma concentrations of (A) glutamine, (B) glycine, (C) asparagine, (D) valine, (E) lysine, and (F) methionine in fasted and fed conditions in piglets divergently selected on low or high residual feed intake $\left(\mathrm{RFI}^{-}\right.$and $\left.\mathrm{RFI}^{+}\right)$and treated with complete Freund adjuvant on $\mathrm{d} 0$. The presented data are least squares means $\pm \mathrm{SE}$. The day (D), line (L), and their interaction $(\mathrm{D} \times \mathrm{L})$ effects are indicated on the charts when significant $\left({ }^{*} P<0.05 ; * * P<0.01 ; * * * P<0.01\right)$

Table 2). The $\mathrm{RFI}^{-}$pigs displayed lower concentrations than $\mathrm{RFI}^{+}$pigs in both fasted and fed states for Ala and Gly $(P<0.05$, Fig. 2B) and in only the fed state for Gln (Fig. 2A), Pro, Ile, Leu $(P<0.05)$, and Hypro $(P=0.07$; Table 2). In contrast, concentrations were greater in $\mathrm{RFI}^{-}$than $\mathrm{RFI}^{+}$pigs in both fasted and fed states for Asp and Glu (fasted state: $P<0.05$ for both AA, fed state: $P<0.05$ and $P=0.08$, respectively; Table 2 and Fig. 2 C) and in only the fasted state for citrulline $($ Cit $)$ and Met $(P<0.05$ and 0.01 respec- tively; Table 3 and Fig. 2F). Other AA concentrations did not differ among lines $(P>0.1)$.

The day $\times$ line interaction was significant for postprandial concentrations of several AA (Ile, Leu, Cit, Met; $P<0.05)$. The concentrations of Ile and Leu varied across days for $\mathrm{RFI}^{-}$but not $\mathrm{RFI}^{+}$pigs. In $\mathrm{RFI}^{-}$ pigs, concentrations increased across days: Ile concentration was greater on $\mathrm{d} 7$ than on $\mathrm{d}-1$ and $1(P<$ 0.05 ; Fig. $2 \mathrm{~F})$, and those of Leu were greater on $\mathrm{d} 3$ and 7 than on $\mathrm{d} 1(P<0.05$ and $P=0.07)$. 
Table 3. Plasma concentrations of AA (nmol/mL) that showed differences from total AA temporal patterns after treatment with complete Freund adjuvant, measured in low and high residual feed intake pigs $\left(\mathrm{RFI}^{-}\right.$ and $\mathrm{RFI}^{+}$lines)

\begin{tabular}{|c|c|c|c|c|c|c|c|}
\hline \multirow[b]{2}{*}{ Item } & \multirow{2}{*}{$\begin{array}{l}\text { Nutritional } \\
\text { status }\end{array}$} & \multirow{2}{*}{$\mathrm{RFI}^{-1}$} & \multirow[b]{2}{*}{$\mathrm{RFI}^{+1}$} & \multirow[b]{2}{*}{ SEM } & \multicolumn{3}{|c|}{$P$-value } \\
\hline & & & & & Line & Time $^{2}$ & Line $\times$ time \\
\hline \multirow[t]{2}{*}{$\operatorname{Arg}$} & Fasted & 32 & 51 & 7 & 0.11 & 0.11 & 0.75 \\
\hline & Fed & 168 & 187 & 16 & 0.39 & 0.59 & 0.05 \\
\hline \multirow[t]{2}{*}{$\mathrm{Cit}^{3}$} & Fasted & 61 & 50 & 3 & 0.02 & 0.07 & 0.93 \\
\hline & Fed & 79 & 69 & 4 & 0.09 & 0.11 & 0.02 \\
\hline \multirow[t]{2}{*}{ His } & Fasted & 36 & 33 & 3 & 0.41 & $0.06(\downarrow)$ & 0.45 \\
\hline & Fed & 65 & 73 & 4 & 0.21 & 0.75 & 0.19 \\
\hline \multirow[t]{2}{*}{ Lys } & Fasted & 55 & 60 & 10 & 0.72 & 0.16 & 0.13 \\
\hline & Fed & 263 & 326 & 27 & 0.11 & $0.03(\uparrow)$ & 0.59 \\
\hline \multirow[t]{2}{*}{ Met } & Fasted & 36 & 28 & 2 & 0.008 & 0.44 & 0.90 \\
\hline & Fed & 67 & 69 & 4 & 0.63 & 0.03 & 0.007 \\
\hline \multirow[t]{2}{*}{$\mathrm{Orn}^{3}$} & Fasted & 61 & 51 & 4 & 0.15 & 0.32 & 0.82 \\
\hline & Fed & 110 & 114 & 6 & 0.63 & 0.30 & 0.17 \\
\hline \multirow[t]{2}{*}{ Phe } & Fasted & 76 & 71 & 3 & 0.29 & 0.11 & 0.45 \\
\hline & Fed & 124 & 135 & 4 & 0.08 & 0.44 & 0.21 \\
\hline \multirow[t]{2}{*}{ Thr } & Fasted & 113 & 106 & 10 & 0.65 & 0.34 & 0.58 \\
\hline & Fed & 217 & 260 & 18 & 0.10 & 0.06 & 0.18 \\
\hline \multirow[t]{2}{*}{ Trp } & Fasted & 35 & 29 & 2 & 0.10 & $0.05(\downarrow)$ & 0.74 \\
\hline & Fed & 64 & 68 & 4 & 0.49 & 0.54 & 0.28 \\
\hline \multirow[t]{2}{*}{ Tyr } & Fasted & 50 & 44 & 4 & 0.21 & 0.31 & 0.92 \\
\hline & Fed & 93 & 103 & 7 & 0.32 & 0.36 & 0.05 \\
\hline \multirow[t]{2}{*}{ Val } & Fasted & 147 & 136 & 10 & 0.46 & $0.01(\downarrow)$ & 0.86 \\
\hline & Fed & 225 & 251 & 14 & 0.22 & 0.64 & 0.12 \\
\hline
\end{tabular}

${ }^{1}$ Least squares means calculated from the concentrations measured every second day from $\mathrm{d}-1$ to $\mathrm{d} 7$ after 1 night fasting (fasted state) and $2 \mathrm{~h}$ after the daily meal (fed state).

${ }^{2}$ Ascending arrows indicate increasing (or tending to increase) concentrations between $\mathrm{d}-1$ and $\mathrm{d} 7$, and descending arrows indicate decreasing (or tending to decrease) concentrations between $\mathrm{d}-1$ and $\mathrm{d} 7$.

${ }^{3} \mathrm{Cit}=$ citrulline, Orn $=$ ornithine.

\section{Tissue Protein Metabolism}

Liver and LM protein synthesis tended to be greater $(P=0.07$ and 0.09 , respectively; Table 4$)$ and liver calpain activity tended to be lower $(P=0.07)$ in $\mathrm{RFI}^{-}$ pigs than in $\mathrm{RFI}^{+}$pigs. Liver and LM proteasome activities did not differ between lines $(P>0.1)$.

\section{DISCUSSION}

A CFA administration was used to generate granulomatous pulmonary lesions and mimic the perturbations resulting from an infection by living respiratory pathogens (Edwards and Slauson, 1983). In pigs, this model is known to induce, within the first $2 \mathrm{~d}$, a febrile response and a reduction in feed intake (Melchior et al., 2004), followed by an increase of the plasma concentration of acute phase proteins such as haptoglobin, pig major acute phase protein, and C-reactive protein (Melchior et
Table 4. Rate of protein synthesis $\left(\mathrm{K}_{\mathrm{s}}\right)$ and specific activities of key enzymes involved in protein degradation in tissues of piglets divergently selected on low or high residual feed intake $\left(\mathrm{RFI}^{-}\right.$and $\left.\mathrm{RFI}^{+}\right)$, measured $8 \mathrm{~d}$ after the complete Freund adjuvant challenge

\begin{tabular}{|c|c|c|c|c|}
\hline Item & $\mathrm{RFI}^{-1}$ & $\mathrm{RFI}^{+1}$ & SEM & $P$-value \\
\hline$N$ & 10 & 11 & & \\
\hline \multicolumn{5}{|l|}{ LM } \\
\hline $\mathrm{K}_{\mathrm{s}}, \% / \mathrm{d}$ & 8.9 & 8.2 & 0.3 & 0.07 \\
\hline Proteasome $^{2}$ & 1,692 & 2,265 & 386 & 0.15 \\
\hline Calpains $^{2}$ & 1,663 & 2,534 & 456 & 0.07 \\
\hline \multicolumn{5}{|l|}{ Liver } \\
\hline $\mathrm{K}_{\mathrm{s}}, \% / \mathrm{d}$ & 85.9 & 76.9 & 5.2 & 0.09 \\
\hline Proteasome $^{2}$ & 170,414 & 153,094 & 10609 & 0.12 \\
\hline Calpains $^{2}$ & 130,255 & 121,422 & 13571 & 0.52 \\
\hline
\end{tabular}

${ }^{1}$ The presented data are least squares means calculated by SAS (SAS Inst. Inc., Cary, NC).

${ }^{2}$ Activities are expressed as $\mathrm{mRFU} \cdot \mathrm{min}-1 \cdot \mathrm{mg}-1$ protein expressed as $\mathrm{mRFU} / \mathrm{min} / \mathrm{mg}$ protein. $\mathrm{RFU}=$ relative fluorescent unit.

al., 2004; Kampman-van de Hoek et al., 2015). Finally, within $1 \mathrm{wk}$, a chronic inflammatory response develops, characterized by a consistently elevated haptoglobin concentration and long-term alterations in blood AA concentrations and metabolism (Melchior et al., 2004; Kampman-van de Hoek et al., 2015). In the present study, the development of the inflammatory response was confirmed by the febrile response on $\mathrm{d} 0$ and 1 , the transient drop in feed intake on d 0 , alterations in blood AA concentrations on $\mathrm{d} 1$ that lasted until $\mathrm{d} 7$ for some AA, and a greater haptoglobin concentration from the day after CFA injection until the end of the experimental period. The high relative weight of the lungs on $\mathrm{d} 8$ is also a characteristic of this inflammatory model, as reported in a previous study using CFA in piglets (Melchior et al., 2005).

\section{Transient Alteration of Plasma Glucose Metabolism in RFI+ Pigs}

Inflammatory states are associated with alterations of glucose metabolism. Inflammatory cytokines such as tumor necrosis factor- $\alpha$ and the macrophage migration inhibitory factor increase glucose uptake and glycolysis in adipose (Porter et al., 2002), muscle (Zentella et al., 1993), and immune (Dietl et al., 2010) cells in vitro and stimulate gluconeogenesis in hepatocytes (Blumberg et al., 1995). Accordingly, in growing pigs injected with bacterial endotoxin, an increased glucose uptake by muscle and viscera is observed, with a concomitant increase in hepatic gluconeogenesis (Bruins et al., 2003) and active transport of glucose at the ileal level (Rakhshandeh et al., 2012). In the same way, in growing pigs, lower pre- and postprandial glucose concentrations can be observed during a 
respiratory infectious challenge compared with those of healthy control pigs (Le Floc'h et al., 2014), and a dramatic drop of glucose concentration occurs during endotoxic shock (Leininger et al., 2000). In the present experiment, fasted glucose concentrations were unchanged throughout the experimental period, showing that fasted glucose homeostasis was not altered. However, the postprandial glucose level, assumed to reflect the fate of dietary glucose, was transiently greater in $\mathrm{RFI}^{+}$pigs on $\mathrm{d} 1$, although the feed intakes of $\mathrm{RFI}^{+}$and $\mathrm{RFI}^{-}$pigs were similar. This greater postprandial glucose concentration in $\mathrm{RFI}^{+}$pigs compared with $\mathrm{RFI}^{-}$pigs might reflect a transiently decreased uptake of dietary glucose for reconstitution of the glycogen pool in both the liver and the muscle even though the glucose:insulin concentration ratio did not vary and an alteration in insulin sensitivity cannot be attested. In that way, greater glycogen content was reported in the muscle and the liver of $\mathrm{RFI}^{-}$healthy pigs than that of $\mathrm{RFI}^{+}$pigs slaughtered at market weight (Lefaucheur et al., 2011). Conversely, Montagne et al. (2014) reported that the increase in glucose concentration after meal ingestion was more pronounced in the $\mathrm{RFI}^{-}$line than in the $\mathrm{RFI}^{+}$line, suggesting that the effect on glucose metabolism discussed in the present experiment was specifically related to different responses of the lines to inflammation.

\section{A Moderate Influence of Inflammation on Whole Body Protein Metabolism}

During severe inflammation, the decrease in protein anabolism (Jahoor et al., 1999; Daiwen et al., 2008) together with the increase in protein catabolism (Bruins et al., 2003) of skeletal muscle results in an enhancement of the release of AA by the muscle into the blood. However, if this release is compensated by an immediate catabolism and utilization for the synthesis of immune proteins, plasma AA concentrations can remain unchanged. Plasma Hypro and urea can be used as markers to evaluate muscle protein and AA catabolism, respectively. Hydroxyproline is formed by the hydroxylation of Pro in proteins. Because Pro and Hypro represent approximately one-third of AA in collagen and Hypro cannot be recycled into Pro for protein synthesis (Phang et al., 2010), its blood concentration is assumed to reflect muscle collagen catabolism. Plasma urea is produced by catabolism of AA, coming mainly from body protein breakdown in the fasted state, to which is added the degradation of AA from dietary proteins by the liver in the fed state.

In the present study, muscle protein degradation was probably very moderate, as indicated by the lack of plasma urea and Hypro increases in the days after
CFA. Furthermore, animals had a positive BW gain, showing that the CFA challenge did not stop muscle protein accretion. However, because Lys is used mainly for protein synthesis, the regular increase in the concentration of Lys in the fed state from $d-1$ to $\mathrm{d} 7$ might indicate a reduction of $\mathrm{N}$ body retention, as reported by Kampman-van de Hoek et al. (2015). A lower uremia was also observed in a previous study using piglets coinfected by a mycoplasma and influenza virus (Le Floc'h et al., 2014). We hypothesized that AA released by protein catabolism might be recycled into new proteins more effectively by the organism during the inflammatory challenge for acute phase protein synthesis, for instance, thus preserving AA from catabolism. Alternatively, we cannot exclude that the reduced feed intake caused by inflammation may have limited urea synthesis, which is mainly influenced by protein intake (Zervas and Zijlstra, 2002).

\section{A Greater Muscle Protein Catabolism in RFI+than RFI-Pigs}

In the present experiment, LM protein turnover was investigated after $8 \mathrm{~d}$ of CFA-induced inflammation. The tendency for greater protein synthesis and lower protein degradation (calpain activity) in the muscle of $\mathrm{RFI}^{-}$pigs suggested greater muscle protein accretion in $\mathrm{RFI}^{-}$pigs. This was also in agreement with their tendency for lower Hypro concentrations across the experiment, at least in the fed state. This did not result in a greater growth in $\mathrm{RFI}^{-}$pigs, probably because $7 \mathrm{~d}$ is too short a period to evaluate a global growth response. These results might reflect either a constitutive difference in muscle protein metabolism between the 2 lines or a difference appearing in only the inflammatory state. The first hypothesis is in agreement with results from a different selection experiment, where unchallenged $\mathrm{RFI}^{-}$gilts displayed reduced protein degradation in LM compared with $\mathrm{RFI}^{+}$gilts, although protein synthesis was unaffected (Cruzen et al., 2013). However, young pigs from this selection scheme did not differ for LM protein synthesis and activity of proteolytic enzymes when measured in healthy conditions (Le Naou et al., 2012). Thus, the observation of differences in protein turnover in the muscle of $\mathrm{RFI}^{-}$and $\mathrm{RFI}^{+}$pigs in the present study $8 \mathrm{~d}$ after CFA administration supports the hypothesis that selection for low RFI favored the preservation of muscular protein accretion specifically during inflammation. This was also suggested in a different selection experiment using a porcine reproductive and respiratory syndrome virus infection challenge, where the slowing down of growth measured during a 28-d period following infection was less in $\mathrm{RFI}^{-}$pigs than in $\mathrm{RFI}^{+}$piglets (Dunkelberger et al., 2015). 


\section{Alteration of Plasma AA Concentrations by the CFA Challenge}

Both $\mathrm{RFI}^{-}$and $\mathrm{RFI}^{+}$pigs displayed a drop in the plasma concentrations of total AA on $\mathrm{d} 1$ in both the fasted and fed states, probably because of the transient anorexia caused by CFA injection on $\mathrm{d} 0$, generating a lower availability of those AA on $\mathrm{d} 1$ in the fasted state and thus rapid uptake for immediate use when supplied by dietary proteins in the postprandial state. Most nonessential AA followed this pattern (Ala, Asn, Asp, Gln, Glu, Gly, Pro, Ser). It cannot be excluded for these AA that the effect of anorexia was combined with an increased specific use for the acute inflammatory response. For example, in a previous experiment CFA-treated piglets displayed lower concentrations of Gln, Gly, and Pro compared with pair-fed control pigs during the first 48 hours after CFA in both the fed and fasted states, and Ala, Asn, and Ser were decreased in the fed state (Melchior et al., 2004). This indicated that anorexia caused by CFA injection cannot be the only explanation for their decreased concentrations, which were therefore supposed to reflect an increased utilization of those AA for immune-specific purposes. Alanine, Asp, Gln, Gly, and Ser plasma concentrations were also reported to be lower after bacterial challenges (Yoo et al., 1997; Jonasson et al., 2007).

Moreover, on d 7, someAA were not back to the basal concentrations observed on $\mathrm{d}-1$ in both the fasted (His, Trp, Val) and fed (Ala, Glu, and, in the RFI line, Ile and Leu) states, indicating that the CFA challenge induced long-lasting alterations in AA metabolism. Among them, His, Trp, and Val displayed (or tended to display) a continuous decline in their fasted concentrations over time. The drop in Trp concentration was to a lesser extent and was observed only in the fasted state, in contrast to the decrease previously observed (Melchior et al., 2004; Le Floc'h et al., 2008). The differences between these studies might be due to the greater Trp content in the diet used in the present experiment $(0.35 \%$ vs. $0.29 \%$, DM basis) since the response in plasma Trp to inflammation depends on the quantity of dietary Trp (Le Floc'h et al., 2008). Other infectious challenges, like Escherichia coli or influenza mycoplasma coinfection, were reported to decrease Trp, His, and Val plasma concentrations in the fasted state (Yoo et al., 1997) or only His (Le Floc'h et al., 2014). Because His, Trp, and Val are glucogenic, as well as ketogenic in the case of Trp, this may reflect an increase of their use by the liver for energetic purpose. Besides its utilization as a precursor of energy, Trp has been reported to be specifically degraded into kynurenine during a CFA challenge (Melchior et al., 2005) by the activation of the indoleamine 2,3-dioxygenase pathway. Interestingly, in Le Floc'h et al. (2008), Val concentrations were unaffected by the CFA challenge, and His concentrations were increased. In a recent study us- ing labeled AA infusion, a lower Val turnover rate was even observed in CFA pigs (Kampman-van de Hoek et al., 2015), suggesting that Val catabolism and/or utilization for protein synthesis were reduced by inflammation. The singular response of plasma Val and His across studies might reveal their sublimiting dietary supply concentrations in a chronic inflammatory situation.

\section{Line Differences in the Metabolism of Some Specific AA}

Interestingly, $\mathrm{RFI}^{-}$pigs had lower concentrations of total AA from $d-1$ to $d$ in the fed state (mainly because of lower concentrations of Ala, Gln, Gly, Leu, Ile, and Pro), suggesting a faster and greater uptake of AA after the meal for immediate use than in $\mathrm{RFI}^{+}$pigs. This greater uptake might support their greater rate of proteosynthesis, a greater use of AA for hepatic gluconeogenesis, or, in the case of Gln, a greater use as energetic fuel in activated immune cells in $\mathrm{RFI}^{-}$pigs (Newsholme, 2001). However, because there was no day $\times$ line interaction, it might be that these differences were not specific to the inflammatory state but a constant difference between lines.

In inflammatory states, muscles increase their release of Ala into the blood, which is then used in the liver for gluconeogenesis (Bruins et al., 2003). In RFI ${ }^{+}$ pigs, Ala concentration was greater in both the fed and fasted states, suggesting that $\mathrm{RFI}^{+}$pigs might have a greater muscular production of Ala to supply the glucose-Ala cycle (Cahill cycle) than $\mathrm{RFI}^{-}$pigs. Moreover, Ile and Leu are 2 major donors of the amino group for Ala synthesis in the muscle. Contrary to what was observed in $\mathrm{RFI}^{-}$pigs, in which Ile and Leu postprandial concentrations increased in comparison to prechallenge concentrations, Ile and Leu postprandial use in $\mathrm{RFI}^{+}$ pigs was maintained across days. This contrasting temporal evolution after CFA administration suggests that the differential use of the Cahill cycle between the 2 lines might be even greater after the CFA challenge than in a basal healthy state. Such results may be associated with the greater glucose postprandial concentration reported in $\mathrm{RFI}^{+}$pigs on 1 after the CFA challenge. A greater Cahill cycle activity in $\mathrm{RFI}^{+}$pigs should lead to increased liver production of Glu and Asp, which are acceptors of the amino group from Ala to form pyruvate then glucose in the liver. Thus, the lower concentrations of Glu and Asp in $\mathrm{RFI}^{+}$pigs in comparison to $\mathrm{RFI}^{-}$pigs is a limitation to our hypothesis.

\section{Conclusion}

The present study confirmed that the inflammation induced by CFA administration can lead to alterations in AA metabolism lasting for at least $7 \mathrm{~d}$. The data 
suggested selection for low RFI favored the preservation of muscle protein accretion during inflammation. The selection on RFI might have also favored preferences for different energetic pathways in RFI+ and RFI- lines: to generate energy, the glucose-Ala cycle might be greater in $\mathrm{RFI}^{+}$pigs than $\mathrm{RFI}^{-}$pigs, reducing their need for other gluconeogenic AA, whereas $\mathrm{RFI}^{-}$pigs would use more other AA for gluconeogenesis and Gln as energetic substrates. Whether these differences between the 2 lines are permanent or specific to inflammatory states needs to be clarified. Nevertheless, these metabolic differences were not associated with fever, haptoglobin, and growth differences, suggesting that both lines coped similarly with the CFA challenge. Contrary to our hypothesis, this experiment showed, in young pigs, no advantage of $\mathrm{RFI}^{+}$ animals in response to an inflammatory challenge.

\section{LITERATURE CITED}

Barea, R., S. Dubois, H. Gilbert, P. Sellier, J. van Milgen, and J. Noblet. 2010. Energy utilization in pigs selected for high and low residual feed intake. J. Anim. Sci. 88:2062-2072. doi:10.2527/jas.2009-2395.

Benhariz, M., O. Goulet, J. Salas, V. Colomb, and C. Ricour. 1997. Energy cost of fever in children on total parenteral nutrition. Clin. Nutr. 16:251-255. doi:10.1016/S0261-5614(97)80037-4.

Blumberg, D., S. Hochwald, M. Burt, D. Donner, and M. F. Brennan. 1995. Tumor-necrosis-factor-alpha stimulates gluconeogenesis from alanine in-vivo. J. Surg. Oncol. 59:220225. doi:10.1002/jso.2930590404.

Bruins, M. J., N. E. P. Deutz, and P. B. Soeters. 2003. Aspects of organ protein, amino acid and glucose metabolism in a porcine model of hypermetabolic sepsis. Clin. Sci. 104:127-141. doi:10.1042/cs1040127.

Clapperton, M., S.C. Bishop, N.D. Cameron, E.J. Glass. 2005. Associations of acute phase protein levels with growth performance and with selection for growth performance in Large White pigs. Anim. Sci. 81:213-220.

Cruzen, S. M., A. J. Harris, K. Hollinger, R. M. Punt, J. K. Grubbs, J. T. Selsby, J. C. M. Dekkers, N. K. Gabler, S. M. Lonergan, and E. Huff-Lonergan. 2013. Evidence of decreased muscle protein turnover in gilts selected for low residual feed intake. J. Anim. Sci. 91:4007-4016. doi:10.2527/jas.2013-6413.

Daiwen, C., Z. Keying, and W. Chunyan. 2008. Influences of lipopolysaccharide-induced immune challenge on performance and whole-body protein turnover in weanling pigs. Livest. Sci. 113:291-295. doi:10.1016/j.livsci.2007.06.011.

Dietl, K., K. Renner, K. Dettmer, B. Timischl, K. Eberhart, C. Dorn, C. Hellerbrand, M. Kastenberger, L. A. Kunz-Schughart, P. J. Oefner, R. Andreesen, E. Gottfried, and M. P. Kreutz. 2010. Lactic acid and acidification inhibit TNF secretion and glycolysis of Human monocytes. J. Immunol. 184:1200-1209. doi:10.4049/jimmunol.0902584.

Doeschl-Wilson, A.B., I. Kyriazakis, A. Vincent, M.F. Rothschild, E. Thacker, L. Galina-Pantoja. 2009. Clinical and pathological responses of pigs from two genetically diverse commercial lines to porcine reproductive and respiratory syndrome virus infection. J. Anim. Sci. 87:1638-1647.
Dunkelberger, J. R., N. J. Boddicker, N. V. L. Serao, J. M. Young, R. R. R. Rowland, and J. C. M. Dekkers. 2015. Response of pigs divergently selected for residual feed intake to experimental infection with the PRRS virus. Livest. Sci. 177:132141. doi:10.1016/j.livsci.2015.04.014.

Edwards, J. F., and D. O. Slauson. 1983. Complete Freund's adjuvant-induced pneumonia in swine-A model of interstitial lung-disease. J. Comp. Pathol. 93:353-361. doi:10.1016/0021-9975(83)90023-3.

Gilbert, H., J. P. Bidanel, J. Gruand, J. C. Caritez, Y. Billon, P. Guillouet, H. Lagant, J. Noblet, and P. Sellier. 2007. Genetic parameters for residual feed intake in growing pigs, with emphasis on genetic relationships with carcass and meat quality traits. J. Anim. Sci. 85:3182-3188. doi:10.2527/jas.2006-590.

Iseri, V. J., and K. C. Klasing. 2013. Dynamics of the systemic components of the chicken (Gallus gallus domesticus) immune system following activation by Escherichia coli: Implications for the costs of immunity. Dev. Comp. Immunol. 40:248-257. doi:10.1016/j.dci.2013.02.005.

Jahoor, F., L. Wykes, M. Del Rosario, M. Frazer, and P. J. Reeds. 1999. Chronic protein undernutrition and an acute inflammatory stimulus elicit different protein kinetic responses in plasma but not in muscle of piglets. J. Nutr. 129:693-699.

Jamin, A., B. Seve, J.-N. Thibault, and N. Floc'h. 2012. Accelerated growth rate induced by neonatal high-protein milk formula is not supported by increased tissue protein synthesis in low-birth-weight piglets. J. Nutr. Metab. 2012:545341. doi:10.1155/2012/545341.

Jonasson, R., B. Essen-Gustavsson, and M. Jensen-Waern. 2007. Blood concentrations of amino acids, glucose and lactate during experimental swine dysentery. Res. Vet. Sci. 82:323-331. doi:10.1016/j.rvsc.2006.08.005.

Kampman-van de Hoek, E., P. Sakkas, W. J. J. Gerrits, J. van den Borne, C. M. C. van der Peet-Schwering, and A. J. M. Jansman. 2015. Induced lung inflammation and dietary protein supply affect nitrogen retention and amino acid metabolism in growing pigs. Br. J. Nutr. 113:414-425. doi:10.1017/S0007114514003821.

Le Floc'h, N., C. Deblanc, R. Cariolet, A. V. Gautier-Bouchardon, E. Merlot, and G. Simon. 2014. Effect of feed restriction on performance and postprandial nutrient metabolism in pigs co-infected with Mycoplasma hyopneumoniae and swine influenza virus. PLoS ONE 9:e104605.

Lefaucheur, L., B. Lebret, P. Ecolan, I. Louveau, M. Damon, A. Prunier, Y. Billon, P. Sellier, and H. Gilbert. 2011. Muscle characteristics and meat quality traits are affected by divergent selection on residual feed intake in pigs. J. Anim. Sci. 89:996-1010. doi:10.2527/jas.2010-3493.

Le Floc'h, N., D. Melchior, and B. Seve. 2008. Dietary tryptophan helps to preserve tryptophan homeostasis in pigs suffering from lung inflammation. J. Anim. Sci. 86:3473-3479. doi:10.2527/jas.2008-0999.

Le Naou, T., N. Le Floc'h, I. Louveau, H. Gilbert, and F. Gondret. 2012. Metabolic changes and tissue responses to selection on residual feed intake in growing pigs. J. Anim. Sci. 90:47714780. doi:10.2527/jas.2012-5226.

Leininger, M. T., C. P. Portocarrero, A. P. Schinckel, M. E. Spurlock, C. A. Bidwell, J. N. Nielsen, and K. L. Houseknecht. 2000. Physiological response to acute endotoxemia in swine: Effect of genotype on energy metabolites and leptin. Domest. Anim. Endocrinol. 18:71-82. doi:10.1016/S0739-7240(99)00064-8.

Melchior, D., N. Meziere, B. Seve, and N. Le Floc'h. 2005. Is tryptophan catabolism increased under indoleamine 2,3 dioxygenase activity during chronic lung inflammation in pigs? Reprod. Nutr. Dev. 45:175-183. doi:10.1051/rnd:2005013. 
Melchior, D., H. Seve, and N. Le Floc'h. 2004. Chronic lung inflammation affects plasma amino acid concentrations in pigs. J. Anim. Sci. 82:1091-1099.

Meunier-Salaun, M. C., C. Guerin, Y. Billon, P. Sellier, J. Noblet, and H. Gilbert. 2014. Divergent selection for residual feed intake in group-housed growing pigs: Characteristics of physical and behavioural activity according to line and sex. Animal 8:1898-1906. doi:10.1017/S1751731114001839.

Montagne, L., F. Loisel, T. Le Naou, F. Gondret, H. Gilbert, and M. Le Gall. 2014. Difference in short-term responses to a highfiber diet in pigs divergently selected for residual feed intake. J. Anim. Sci. 92:1512-1523. doi:10.2527/jas.2013-6623.

Newsholme, P. 2001. Why is L-glutamine metabolism important to cells of the immune system in health, postinjury, surgery or infection? J. Nutr. 131:2515S-2522S.

Pastorelli, H., J. van Milgen, P. Lovatto, and L. Montagne. 2012. Meta-analysis of feed intake and growth responses of growing pigs after a sanitary challenge. Animal 6:952-961. doi:10.1017/S175173111100228X.

Phang, J. M., W. Liu, and O. Zabirnyk. 2010. Proline metabolism and microenvironmental stress. Annu. Rev. Nutr. 30:441463. doi:10.1146/annurev.nutr.012809.104638.
Porter, M. H., A. Cutchins, J. B. Fine, Y. Bai, and M. Digirolamo. 2002. Effects of TNF- $\alpha$ on glucose metabolism and lipolysis in adipose tissue and isolated fat-cell preparations. J. Lab. Clin. Med. 139:140-146. doi:10.1067/mlc.2002.121552.

Rakhshandeh, A., J. C. M. Dekkers, B. J. Kerr, T. E. Weber, J. English, and N. K. Gabler. 2012. Effect of immune system stimulation and divergent selection for residual feed intake on digestive capacity of the small intestine in growing pigs. J. Anim. Sci. 90:233-235. doi:10.2527/jas.53976.

Yoo, S. S., C. J. Field, and M. I. McBurney. 1997. Glutamine supplementation maintains intramuscular glutamine concentrations and normalizes lymphocyte function in infected early weaned pigs. J. Nutr. 127:2253-2259.

Young, J. M., W. Cai, and J. C. M. Dekkers. 2011. Effect of selection for residual feed intake on feeding behavior and daily feed intake patterns in Yorkshire swine. J. Anim. Sci. 89:639647. doi:10.2527/jas.2010-2892.

Zentella, A., K. Manogue, and A. Cerami. 1993. Cachectin/TNFmediated lactate production in cultured myocytes is linked to activation of a futile substrate cycle. Cytokine 5:436-447. doi:10.1016/1043-4666(93)90033-2.

Zervas, S., and R. T. Zijlstra. 2002. Effects of dietary protein and oathull fiber on nitrogen excretion patterns and postprandial plasma urea profiles in grower pigs. J. Anim. Sci. 80:3238-3246. 